\title{
Analysis of the sex ratio in Bradysia matogrossensis (Diptera, Sciaridae)
}

\author{
Lincoln S. Rocha and André Luiz P. Perondini
}

\begin{abstract}
In sciarid flies, the control of sex determination and of the progeny sex ratio is exercised by the parental females, and is based on differential X-chromosome elimination in the initial stages of embryogenesis. In some species, the females produce unisexual progenies (monogenic females) while in others, the progenies consist of males and females (digenic females). The sex ratio of bisexual progenies is variable, and departs considerably from 1:1. Bradysia matogrossensis shows both monogenic and digenic reproduction. In a recently established laboratory strain of this species, $15 \%$ of the females were digenic, $10 \%$ produced only females, $13 \%$ produced only males, and $62 \%$ produced progenies with one predominant sex (33\% predominantly of female and $29 \%$ predominantly male progenies). These progeny sex ratios were maintained in successive generations. Females from female-skewed progenies yielded female- and male-producing daughters in a 1:1 ratio. In contrast, daughters of females from male-skewed progenies produce bisexual or male-skewed progenies. The X-chromosome of B. matogrossensis shows no inversion or other gross aberration. These results suggest that the control of the progeny sex ratio (or differential X-chromosome elimination) involves more than one locus or, at least, more than one pair of alleles. The data also suggest that, in sciarid flies, monogeny and digeny may share a common control mechanism.
\end{abstract}

\section{INTRODUCTION}

Within the dipteran family Sciaridae, there are species in which the females produce progenies of only one sex, males and females (monogenic species), and others in which the progenies consist of both sexes (digenic or amphigenic species) (Metz, 1938; Gerbi, 1986; Perondini, 1998).

The type of progeny produced is conditioned by the parental female genotype which determines the differential elimination of sex chromosomes in the embryos, thereby producing specific female or male karyotypes. The embryos of sciarid flies start development with a double dosis of each autosome, but with three $\mathrm{X}$-chromosomes, two of which are of paternal origin (reviewed in Metz, 1938; Gerbi, 1986; Perondini, 1998; Sánchez and Perondini, 1999). During the initial stages of embryonic development, one or two X-chromosomes of paternal origin are eliminated from the nuclei of the putative somatic regions of the embryos, establishing the XX;2A and X0;2A karyotypes of females and males, respectively (DuBois, 1933; Perondini et al., 1986). The proportion of embryos that eliminates one or two Xs in a given progeny determines the sex ratio of that offspring. The ensuing sex determination of the individuals seems to be brought about by the X:A ratio, as in Drosophila (da Cunha et al., 1994; Perondini, 1998; Sánchez and Perondini, 1999).

Although the sex ratio of individual progenies is highly distorted ( $100 \%$ of a given sex), in monogenic species the populational sex ratio is nearly $1: 1$ because females producing all-male progenies (androgenic females) and those producing all-female progenies (gynogenic fe- males) occur in equal proportions (Metz, 1938). Sciara coprophila is a monogenic species with each progeny being composed exclusively of a given sex; individuals of the opposite sex are very rare (Metz and Schmuck, 1929a). In digenic species, the sex ratio is extremely variable, departing considerably from the 1:1 ratio above. In such species, the full range of sex ratios occurs, from all-female to allmale progenies, with bisexual progenies exhibiting different male:female ratios (Metz, 1938). In digenic strains of Sciara ocellaris most progenies are bisexual with singlesex progenies being less frequent (or absent) (Metz and Lawrence, 1938; Davidheiser, 1943; Mori et al., 1979). These two examples, $S$. coprophila and S. ocellaris, may be considered as paradigms of the mode for progeny sex ratio determination in sciarid flies.

We have found a sciarid species, Bradysia matogrossensis, with a tendency to produce unisexual offspring, although bisexual progenies were frequently recovered. In this report, we describe the monogenic characteristics of this species, as well as the digenic mode of reproduction.

\section{MATERIAL AND METHODS}

A laboratory colony of Bradysia matogrossensis (Lane, 1959) was established from specimens collected in the campus of the University of São Paulo, São Paulo, Brazil. The colony was kept in 250-ml glass vials containing a layer of $4 \%$ plain agar, and the flies were fed dried, ground bean leaves mixed with baker's yeast.

For the sex ratio analysis, individuals were taken randomly from the colony and mating pairs were set up in individual flasks. The adult offspring of each cross were 
recovered from the first day of emergence up to the last emerging flies (usually about 10 days later), counted and separated by sex.

In some experiments, the sex ratio analysis was conducted over generations, each of which was initiated with females derived from progenies with a known sex ratio. This was not an easy task in $B$. matogrossensis since the adult flies live just 3-4 days, a period shorter than that necessary for all flies of a given progeny to emerge. As in other species, e.g. S. ocellaris (Mori, 1978), the adult males emerge 1-2 days before the females. Hence, the absence of males at the beginning of the emergence period would indicate that the progeny would be an all-female or, at least, bisexual with few males. The reverse was also true. This criterion was useful for the females used to initiate each generation. However, these females were discarded if the first indication of the sex ratio did not confirm the progeny from which they derived.

Salivary gland polytene chromosomes were prepared by the standard lactic-acetic squash technique using late fourth instar larvae. More details of these experiments are given in the appropriate section of Results.

\section{RESULTS}

\section{Sex ratio in a laboratory population}

A sample of about 100 pair of matings was randomly selected from the stock and transferred to individual flasks from which 72 progenies of 33-123 individuals each were recovered. The sex ratio distribution of this sample is shown in Figure 1. For this analysis, the all-male and allfemale progenies were isolated from those composed of individuals of both sexes. The bisexual progenies were grouped into five classes according to their frequency of males, i.e., 1-19, 20-39, ....,80-99\%.

Clearly the variation in the progeny sex ratio of Bradysia matogrossensis followed a trimodal distribution, with peaks at both extremes of the scale $(85 \%$ of progenies), and a broad intermediate class of bisexual offspring (15\% of progenies) (Figure 1A). Within the progenies grouped at the extremes of the scale, $23 \%$ were unisexual (10\% all-females and $13 \%$ all-males), while the other $62 \%$ produced progenies in which one sex predominated. Among these, $33 \%$ showed predominance of females and $29 \%$ of males. Hence, there was a tendency of B. matogrossensis females to produce progenies at the extremes of the sex ratio scale. This tendency was further analyzed by rearranging the progenies with one predominant sex into smaller sex ratio intervals. As shown in Figure $1 \mathrm{~B}$, the frequency of progenies with rare individuals of the opposite sex was higher near the single-sex classes and decreased toward intermediate values as the sex ratio moved away from these extremes. In other words, the frequency of one predominant sex progenies was inversely correlated to number of the rare individuals they contained such that the higher the frequency, the smaller the number of rare sex individuals.

The number of rare sex individuals in predominantly one-sex progenies contributed very little to the total number of adults produced in a given generation. Thus, from the 24 predominantly female progenies, 1313 females and only 57 males were recovered, while from the 20 predominantly male progenies, 1904 males and only 47 females were recovered. Rare males occurred more frequently than rare females $(\mathrm{P}=0.0059,2 \times 2$ contingency table $)$.

\section{Sex ratio over generations}

Although the preceding analysis showed that there were five types of progenies in the population of $B$. matogrossensis studied (two single-sex types, two pre-
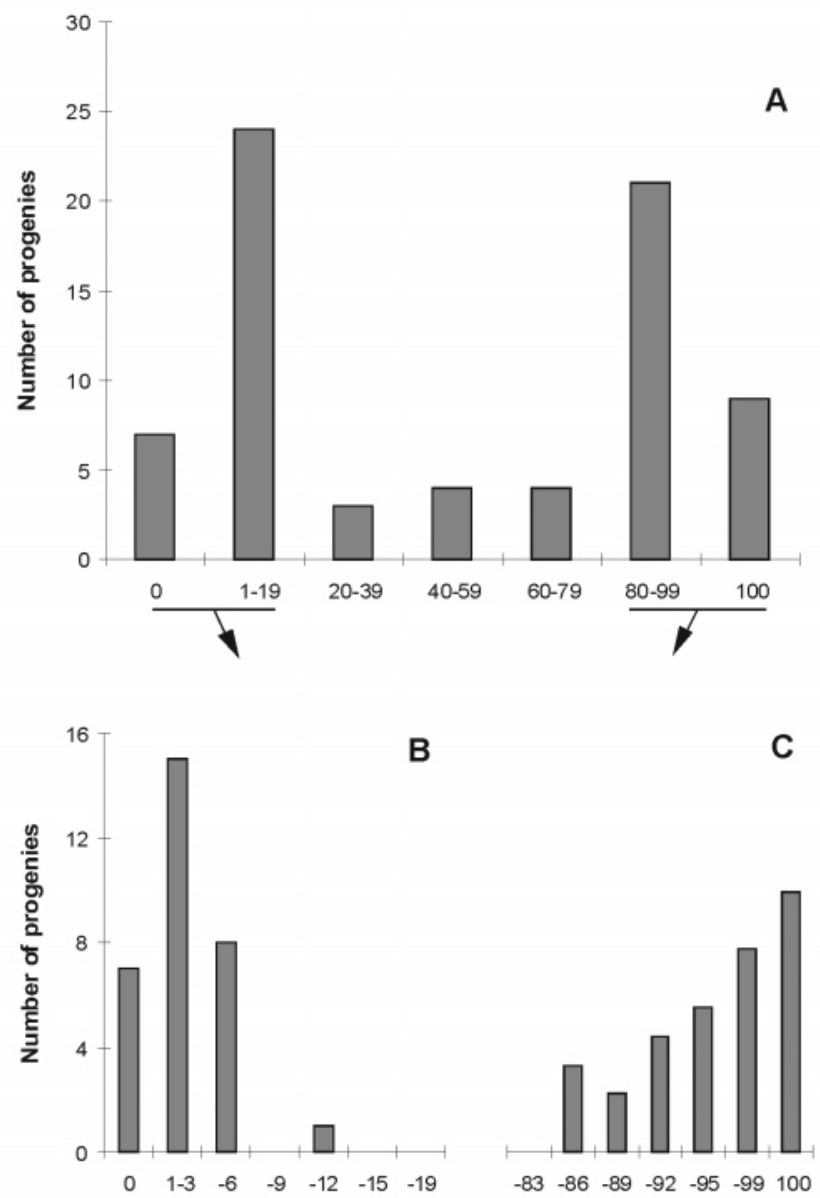

Figure 1 - Progeny sex ratio distribution in females $(\mathrm{N}=72)$ from a laboratory population of B. matogrossensis. A, Frequency distribution of females according to the sex ratio of their progenies, expressed as the proportion of males/progeny. The all-female and all-male classes were isolated and the bisexual progenies were grouped into five classes of $20 \%$ intervals. The female- and male-skewed classes (indicated by horizontal bars) were reanalyzed using smaller class intervals (3\%) (panels B and C, respectively). Note the decreasing frequency of two-sex progenies as the number of the rare, opposite sex increases. 
dominantly one-sex types and one bisexual type), and that females producing single-sex progenies occurred in a 1:1 ratio, it did not provide information about the mechanism(s) which determined the progeny sex ratio.

In the next experiment, the females producing unisexual progenies were grouped with those producing predominantly one-sex progenies based on the prevalent sex, and were designated female producers or male producers. From predominantly female offspring (1 male:69 females) produced by a female from the stock, 30 sister females were crossed with males from the stock, and 16 progenies were recovered and the sex ratio of each recorded. From one predominantly female progeny, 30 new females were isolated and crossed with stock males. The procedure was repeated for seven generations. Table I shows that females selected from predominantly or all-female progenies repeatedly generated both female-producing and male-producing females, with a few digenic females. Considering the eight generations together, 71 females were female producers and 65 were male producers, which corresponded to a ratio that did not differ significantly from $1: 1$. At each generation, the ratio of these two types of females was also $1: 1$, except for the sixth generation which, for some unknown reason, contained more femaleproducing than male-producing females $(18: 3$; $\mathrm{P}<0.005)$. Although the progeny size (number of individuals) was quite variable (Table I), progeny sex ratios were not correlated with this variation.

In another experiment, one female from the stock produced bisexual progeny of 27 males and 70 females. Full-sib crosses were done with 26 of these females, resulting in a progeny sex ratio distribution different from that observed in the previous experiment. In addition to the predominantly female and predominantly male progenies, bisexual progenies (50-79\% males) were also prominent (Figure 2A). To initiate the next generation, two experiments were done. In one, 24 females were collected from a predominantly female progeny ( 2 males: 82 females), and in other, 18 females were recovered from a bisexual progeny (with a predominance of males (78 males, 11 females). All females were crossed with males from the same stock. The former produced the two types of predominantly one-sex progenies, in about equal proportions (Figure 2B), while the latter yielded all-male, predominantly male, and bisexual progenies (Figure 2B'). From the bisexual progeny, nine females were crossed with their brothers and produced only bisexual progenies (Figure 2C).

Analysis of polytene chromosomes

In the monogenous species $S$. coprophila (Crouse, 1960) and Sciara impatiens (Carson, 1946), the gynogenic females are heterozygous for a long inversion in the $\mathrm{X}$ chromosome, while the androgenic females are homozygous for the standard chromosome. No inversion is present on the X-chromosome of digenic species (Gerbi, 1986). Since gynogenic and androgenic females exist in $B$. matogrossensis, an analysis was necessary to establish the status of the X-chromosome.

For this analysis, 20 females from a female-skewed progeny (1 male:89 females) were crossed. From each cross, 10-12 slides were prepared from larval salivary glands and quickly examined by light microscopy. The best eight slides per cross were then examined in detail. Based on the genetic system of Sciara, the analysis of eight individuals per cross correspond to a $99.9 \%$ chance of recovering the two chromosomes in cases where the females are heterozygous (Perondini et al., 1983). Since the 20 females derived from a cross that was strongly female-skewed, it would be expected that half of them would be female producers and half male producers, based on the results described above. If a structural difference exists between the $\mathrm{X}$ chromosome of female-producing and male-producing females, as in S. coprophila (Crouse, 1960), one would expect to recover the two types of chromosomes in the progenies of the 20 females examined. However, in the 160 larvae examined, only one form of $\mathrm{X}$-chromosome was found with uniform pairing along its entire length and no inversion or other gross aberration (Figure 3 ).

\section{DISCUSSION}

The present analysis showed that the progeny sex ratio in B. matogrossensis was conditioned by the parental

Table I - Progeny classes and number of individuals per progeny produced by B. matogrossensis females in eight generations.

\begin{tabular}{|c|c|c|c|c|c|c|c|c|c|c|}
\hline \multirow{2}{*}{ Generations } & \multirow{2}{*}{$\begin{array}{l}\text { No. of } \\
\text { crosses }\end{array}$} & \multirow{2}{*}{$\begin{array}{l}\text { All-females } \\
\mathrm{N}^{*}(\mathrm{~F})^{*}\end{array}$} & \multirow{2}{*}{\multicolumn{2}{|c|}{$\begin{array}{l}\text { Predominantly female } \\
\mathrm{N}^{*} \quad(\mathrm{~F}>\mathrm{M})^{*}\end{array}$}} & \multicolumn{2}{|c|}{ Bisexual } & \multicolumn{2}{|c|}{ Predominantly male } & \multicolumn{2}{|c|}{ All-male } \\
\hline & & & & & $\mathrm{N}^{*}$ & $(\mathrm{~F}: \mathrm{M})^{*}$ & $\mathrm{~N}^{*}$ & $(\mathrm{M}>\mathrm{F})^{*}$ & & $(\mathrm{M})^{*}$ \\
\hline G1 & 1 & ------ & 1 & $(60>1)$ & & ------ & & ----- & & ----- \\
\hline $\mathrm{G} 2$ & 16 & $2(105 \pm 22)$ & 3 & $(67 \pm 23>2 \pm 1)$ & 2 & $(24 \pm 1: 73 \pm 57)$ & 3 & $(63 \pm 19>3 \pm 2)$ & 6 & $(68 \pm 23)$ \\
\hline G3 & 18 & 1 & 8 & $(110 \pm 32>2 \pm 1)$ & 1 & $(18: 105)$ & 2 & $(107 \pm 29>7 \pm 9)$ & 6 & $(97 \pm 42)$ \\
\hline G4 & 29 & 1 (111) & 12 & $(77 \pm 21>4 \pm 2)$ & 0 & ------ & 8 & $(67 \pm 25>2 \pm 1)$ & 8 & $(75 \pm 25)$ \\
\hline G5 & 27 & $1(91)$ & 6 & $(87 \pm 11>5 \pm 3)$ & 3 & $(59 \pm 29: 19 \pm 16)$ & 16 & $(90 \pm 23>3 \pm 2)$ & 1 & (47) \\
\hline G6 & 21 & $6(66 \pm 28)$ & 12 & $(69 \pm 26>1 \pm 0.5)$ & 0 & ------ & 2 & $(61 \pm 21>2 \pm 1)$ & 1 & (50) \\
\hline G7 & 15 & $1(55)$ & 8 & $(74 \pm 28>3 \pm 2)$ & 0 & ----- & 2 & $(103 \pm 32>1 \pm 0.5)$ & 4 & $(58 \pm 33)$ \\
\hline G8 & 16 & $1(62)$ & 8 & $(47 \pm 11>3 \pm 2)$ & 1 & $(34: 63)$ & 6 & $(52 \pm 19>2 \pm 1)$ & 0 & ---- \\
\hline
\end{tabular}

$* \mathrm{~N}=$ Number of progenies. Values in parentheses correspond to the mean $\pm \mathrm{SD}$ of the number of individuals per progeny. 

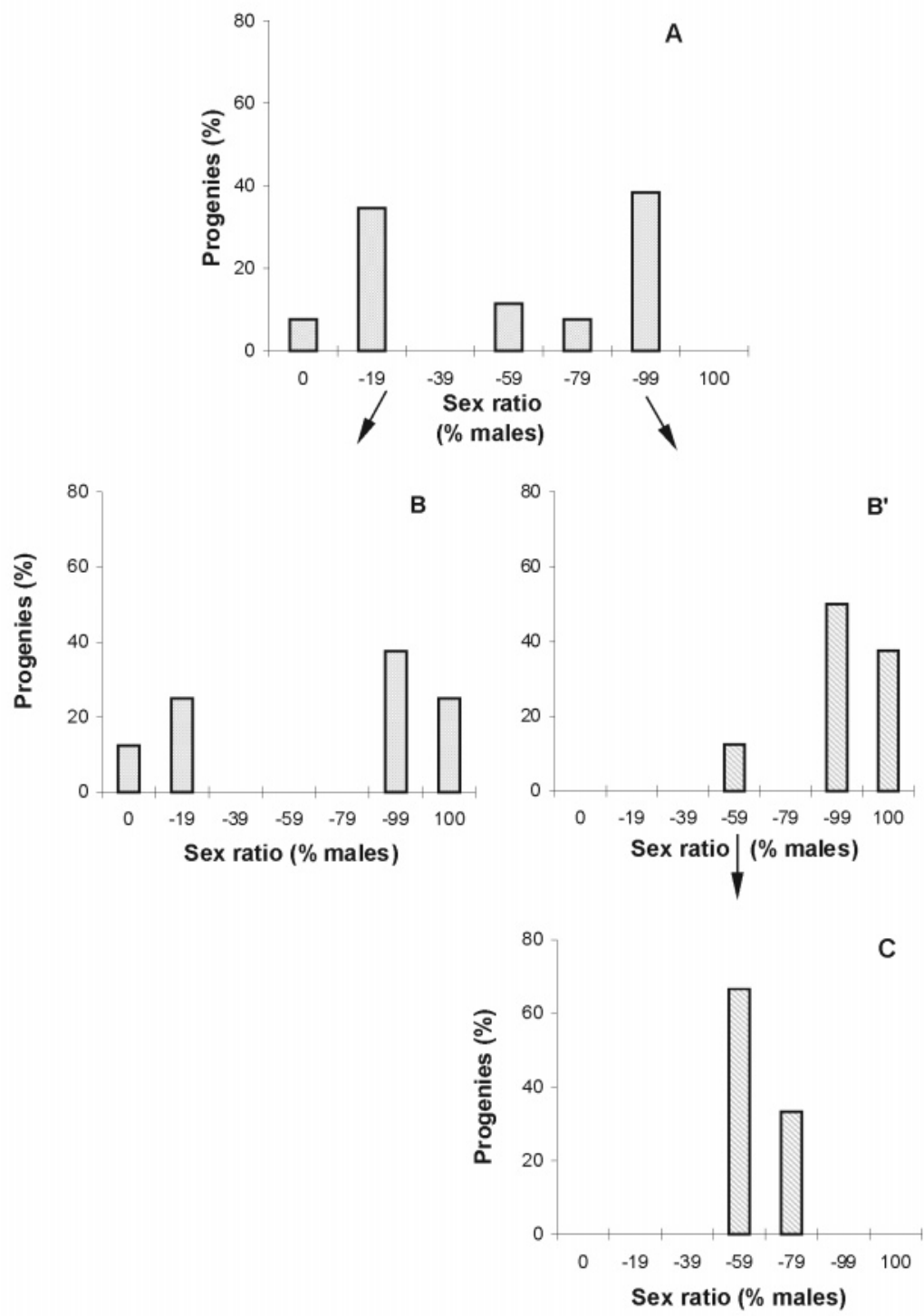

Figure 2 - Sex ratio distribution of progenies produced by females from female-skewed or male-skewed progenies. Females $(\mathrm{N}=26)$ recovered from a bisexual progeny (27 male:70 females) produced the progenie classes shown in A. Females selected from the progeny interval 1-19\% produced the female- and male-skewed progenies shown in B. In contrast, females collected from a predominantly male progeny (interval 8099\%) produced bisexual and male-skewed progenies (B'). Females selected from the bisexual class in B' produced only bisexual progenies (C).

females, as in other sciarid flies such as S. coprophila (Moses and Metz, 1928) and S. ocellaris (Liu, 1968). Based on the progeny sex ratio classes, three types of females were observed: those that produced females, those that produced males and those with digenic progeny. Since these three types occurred repeatedly, and in significant frequencies, they can be considered as normal for the species. B. matogrossensis thus combines monogeny and digeny, the two modes of reproduction described so far in sciarid flies (Metz, 1938; Gerbi, 1986; Perondini, 1998; Sánchez and Perondini, 1999).

Conspicuous differences are, nonetheless, present. In the monogenic S. coprophila (Metz and Schmuck 1929b; Guatimosim, 1996), single-sex progenies are prevalent, with the occurrence of individuals of the "op- posite sex" in a progeny (i.e., a male in an all-female progeny or vice versa) being very rare. As a consequence, progenies with one predominant sex seldom occur. In contrast, in B. matogrossensis progenies of the latter type, with either rare females or males, are very frequent and occur at frequencies similar to, or greater than, the number of single-sex progenies. However, progenies with one predominant sex present a peculiar frequency distribution since they are more frequent near the extremes (singlesex progenies) of the sex ratio scale, and their frequency decreases as the number of rare sex individuals increases. Of course, as number of rare sex individuals in the progenies increases, the progenies would be classified as bisexual, and no longer as predominantly of the one-sex type.

The difficulty therefore is where to set the limit be- 


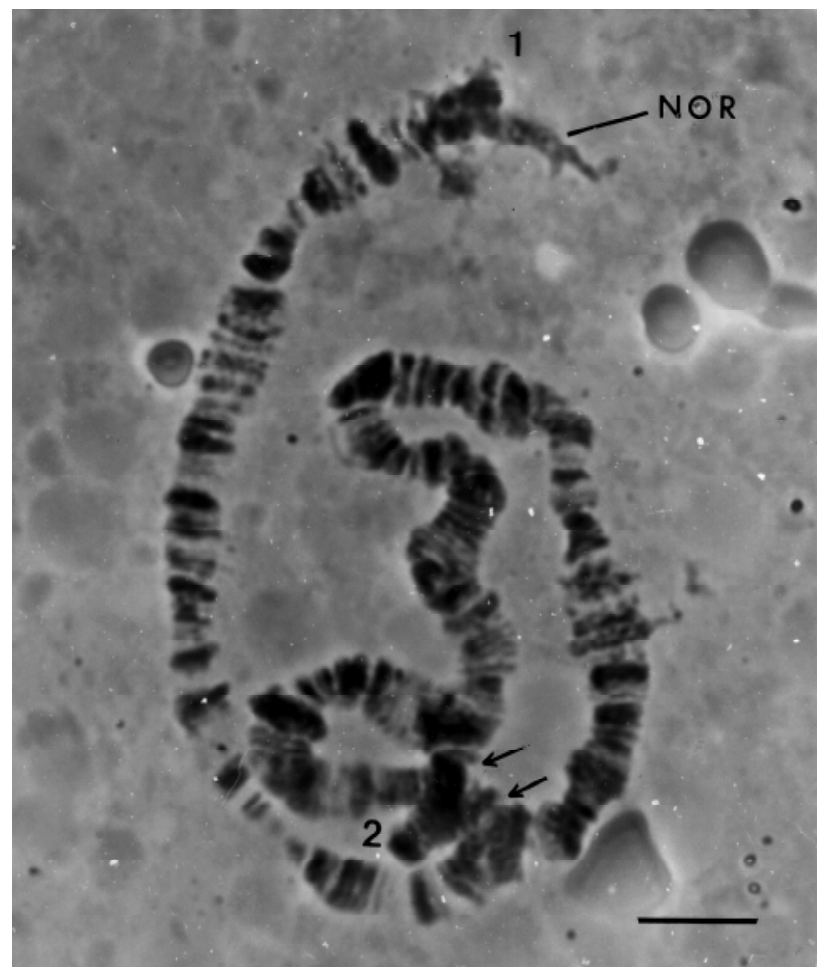

Figure 3 - X-chromosome of a salivary gland cell from a female larva of $B$. matogrossensis. Note the folding of the chromosome due to repeats (arrows) (a common finding in sciarid polytene X-chromosomes; see Perondini and Dessen, 1985), the nucleolus organizing region (NOR) and pairing of the homologs along the entire length of the chromosome. 1 and 2 denote the extremities of the chromosome. Bar $=10 \mu \mathrm{m}$.

tween a bisexual and a predominantly one-sex progeny. For the digenic $S$. ocellaris, Davidheiser (1943) considered females that produced less than $5 \%$ of the rare sex in their progenies to be monogenic, with rare sex individuals being the result of errors in the mechanism of sex determination. The appearance of rare sex individuals in singlesex progenies of strictly monogenic species such as $S$. coprophila was similarly interpreted by Metz (1938). The present analysis strenghtens this interpretation. The decreasing frequency of predominantly one-sex progenies as the distance from single-sex classes increases suggests, but does not prove, that rare sex individuals (or predominantly one-sex progenies) are a consequence of errors in the mechanism of sex determination. These rare sex flies in predominantly one-sex progenies are however perfectly normal males or females with the correct set of chromosomes. Based on the sex determination mechanism in Sciara, such "errors" would include the elimination of an additional $\mathrm{X}$ chromosome in some embryos (producing the few males in all-female progenies) or the lack of elimination of a second $\mathrm{X}$, giving rise to the few females in predominantly male progenies (Metz, 1938; Perondini, 1998; Sánchez and Perondini, 1999). Errors of this sort may also occur in different nuclei of the same embryos, producing individuals with a mixture of male and female tissues (gynandromorphs) (DuBois, 1933; Metz and Lawrence, 1938; Mori et al., 1979; Mori and Perondini, 1980, 1984; Perondini, 1998; Sánchez and Perondini, 1999). However, it is more conceivable to admit that the origin of the rare individuals in predominantly one-sex progenies is not the result of errors in the process of X-chromosome elimination during the embryonic period, but rather, that the monogenous parental females produced a few oocytes containing biased instructions for chromosome elimination. This interpretation was initially proposed by Metz (1938), who considered the problem on a quantitative basis, namely, that female-producing and male-producing females differed in their combination of genes (or alleles) and produced eggs with different thresholds of a "signal" that coordinated the elimination of one or two Xchromosome in the embryos. The rare individuals would develop from oocytes in which the threshold value was erroneously set so close to the limit that elimination would be the opposite of what was expected. Sánchez and Perondini (1999) have proposed a model for the control of $\mathrm{X}$-chromosome elimination in which the existence of a maternal factor with different threshold levels in maleand female-determined oocytes is formally explained. The observation in B. matogrossensis that rare males in predominantly female progenies were more frequent than rare females in predominantly male progenies, a situation also found in S. coprophila (Metz and Schmuck, 1929a), may also be accounted for by the model.

According to these interpretations, predominantly one-sex progenies would represent deviations from singlesex progenies, rather than independent classes. In other words, if different genotypes do exist and determine the progeny sex ratio intervals as proposed by Metz (1938), there should be no specific genotypes for the predominantly one-sex classes. These assumptions and interpretation require confirmation. The difficulty at the moment is that there is no information about the genes involved in the control of X-chromosome elimination (or sex predetermination) in sciarid flies. The results of this study showing that females derived from female-skewed progenies consistently produced two types of daughters (male producers and female producers) in a 1:1 ratio, and that females derived from male-skewed progenies produced daughters which gave origin to male-skewed progenies, indicate that femaleness and maleness are governed by different genotypes. Moreover, the results are incompatible with the existence of a simple pair of alleles: either more than one locus or more than one pair of alleles is involved in this process.

The presence of a long inversion on the X-chromosome of $S$. coprophila is assumed to be partly responsible for the strictly monogenic mode of reproduction in this species. The lack of recombination would have fixed genotypes conditioning exclusive monogeny (Metz and Smith, 1931; Metz and Schmuck, 1931; Metz, 1938; Crouse, 1960). 
In a digenic strain of $S$. ocellaris, no inversion is present on the X-chromosome (Perondini et al., 1983; Perondini and Dessen, 1985), and recombination does occur on this chromosome (Guatimosim and Perondini, 1995). Hence, it is possible that different combinations of alleles (or genes) involved in X-chromosome elimination would be formed, giving origin to the different classes of sex ratios (Metz, 1938; Crouse, 1960; Perondini, 1998), including single-sex progeny, albeit at low frequency (Mori et al., 1979). The condition in B. matogrossensis, in which single-sex and bisexual progenies occur at significant frequencies, with no inversion in the X-chromosome, suggests that the mechanism governing $\mathrm{X}$-elimination in this species is more similar to that present in digenic species than in monogenic ones. The main difference between progeny sex ratio distributions in $B$. matogrossensis and $S$. ocellaris may be explained solely in terms of the frequency of alleles conditioning the different progeny sex ratio classes. According to this interpretation, monogeny and digeny in sciarid flies would have the same genetic basis, a view assumed by Perondini (1998) and Sánchez and Perondini (1999), but not always clear in previous studies (Metz, 1938; Hamilton, 1967; Bull, 1983; Haig, 1993).

\section{ACKNOWLEDGMENTS}

The authors thank Dalton S. Amorin for identifying the species. Research supported in part by FINEP and the European Union (contract C11*-CT94-0071). L.S.R. was the recipient of an IC studentship (PIBIC/USP) and A.L.P.P. is a research fellow of CNPq. Publication supported by FAPESP.

\section{RESUMO}

Nas espécies de sciarídeos, o controle da determinação do sexo dos indivíduos, assim como da proporção sexual das progênies, é feito pelas fêmeas parentais e baseia-se em um mecanismo diferencial de eliminação de cromossomo $\mathrm{X}$ nas primeiras fases do desenvolvimento embrionário. Existem espécies cujas fêmeas produzem progênies de um único sexo (fêmeas monogênicas) e outras cujas proles incluem machos e fêmeas (fêmeas digênicas). A proporção sexual nas proles bissexuais é variável, desviando-se significativamente de 1:1. Bradysia matogrossensis apresenta características dos dois modos de reprodução. Em uma população recém-introduzida no laboratório, existem $15 \%$ de fêmeas digênicas, $10 \%$ de fêmeas produtoras de fêmeas, $13 \%$ de fêmeas produtoras de machos e $62 \%$ de fêmeas em cujas proles um sexo foi predominante sobre o outro (33\% de progênies de fêmeas com raros machos e $29 \%$ de proles de machos com raras fêmeas). Foi mostrado que estas condições se mantêm sem alterações significativas por gerações sucessivas. Fêmeas derivadas de progênies com predominância de fêmeas produzem sempre filhas produtoras de fêmeas e produtoras de machos, na proporção de 1:1. Ao contrário, fêmeas derivadas de progênies bissexuais (com predominância de machos) produzem filhas que dão origem a proles apenas de machos ou, então, com predominância de machos. O cromossomo X de B. matogrossensis não apresenta inversão ou outra aberração visível citolo- gicamente. Os resultados sugerem que no controle da eliminação do cromossomo X deve existir mais que um loco ou, então, mais que um simples par de alelos. Sugerem, também, que os dois modos de reprodução dos sciarídeos, monogenia e digenia, devem ter mecanismos de controle similares, uma hipótese nem sempre considerada em estudos anteriores.

\section{REFERENCES}

Bull, J.J. (1983). Evolution of Sex Determining Mechanisms. W.A. Benjamin Cummings, Menlo Park.

Carson, H.L. (1946). The selective elimination of inversion dicentric chromatids during meiosis in the eggs of Sciara impatiens. Genetics 31: 95-113.

Crouse, H.V. (1960). The nature of the influence of X-translocation on sex of progeny in Sciara coprophila. Chromosoma 11: 146-166.

da Cunha, P.R., Granadino, B., Perondini, A.L.P. and Sánchez, L. (1994). Dosage compensation in sciarids is achieved by hypertranscription of the single X chromosome in males. Genetics 138: 787-790.

Davidheiser, B. (1943). Inheritance of the X chromosome in exceptional males of Sciara ocellaris (Diptera). Genetics 28: 193-195.

DuBois, A.M. (1933). Chromosome behavior during cleavage in the eggs of Sciara coprophila (Diptera) in relation to the problem of sex determination. Z. Zellforsch. Mikrosk. Anat. 19: 595-614.

Gerbi, S. (1986). Unusual chromosome movements in sciarid flies. In: Results and Problems in Cell Differentiation. Germ Line-Soma Differentiation (Hennig, W., ed.). Vol. 13. Spring-Verlag, Berlin, pp. 71-104.

Guatimosim, V.M.B. (1996). Efeitos da radiação UV no processo de eliminação de cromossomos $\mathrm{X}$ nos núcleos somáticos do díptero Sciara ocellaris (Diptera; Sciaridae). Doctoral thesis, Universidade de São Paulo, São Paulo, SP.

Guatimosim, V.M.B. and Perondini, A.L.P. (1995). Linhagem trissômica para o cromossomo X em Sciara ocellaris: desvios nas proporções fenotípicas. Rev. Bras. Genet. 18 (Suppl.): 309 (Abstract).

Haig, D. (1993). The evolution of unusual chromosomal system in sciarid flies: intragenomic conflict and the sex ratio. J. Evol. Biol. 6: 249-261.

Hamilton, W.D. (1967). Extraordinary sex ratios. Science 156: 477-488.

Liu, P.Y. (1968). Estudo biológico de cultura de Bradysia tritici (Diptera, Sciaridae) parasitada por gregarina. Master's thesis, Universidade de São Paulo, São Paulo, SP.

Metz, C.W. (1938). Chromosome behavior, inheritance and sex determination in Sciara. Am. Nat. 72: 485-520.

Metz, C.W. and Lawrence, E.G. (1938). Preliminary observations on Sciara hybrids. Heredity 29: 179-186.

Metz, C.W. and Schmuck, M.L. (1929a). Unisexual progenies and the sex chromosome mechanism in Sciara. Proc. Natl. Acad. Sci. USA 15: 863-866.

Metz, C.W. and Schmuck, M.L. (1929b). Further studies on the chromosomal mechanism responsible for unusual progenies in Sciara. Tests of "exceptional" males. Proc. Natl. Acad. Sci. USA 15: 867-870.

Metz, C.W. and Schmuck, M.L. (1931). Studies on sex determination and the sex chromosome mechanism in Sciara. Genetics 16: 225-253.

Metz, C.W. and Smith, H.B. (1931). Further observation on the nature of the X-prime (X') chromosome in Sciara. Proc. Natl. Acad. Sci. USA 17: $195-198$

Mori, L. (1978). Ginandromorfos e determinação do sexo em Sciara ocellaris. Doctoral thesis, Universidade de São Paulo, São Paulo, SP.

Mori, L. and Perondini, A.L.P. (1980). Errors in the elimination of X chromosomes in Sciara ocellaris. Genetics 94: 663-673.

Mori, L. and Perondini, A.L.P. (1984). An analysis of Sciara ocellaris gynandromorphs and the morphogenetic fate map of presumptive adult cuticular structures. J. Exp. Zool. 230: 29-35.

Mori, L., Dessen, E.M. and Perondini, A.L.P. (1979). A gene that modifies the sex ratio in a bisexual strain of Sciara ocellaris. Heredity 42: 353-357.

Moses, M.S. and Metz, C.W. (1928). Evidence that the female is responsible for the sex ratio in Sciara (Diptera). Proc. Natl. Acad. Sci. USA 14: $928-930$

Perondini, A.L.P. (1998). Elimination of X chromosomes and the problem of sex determination in Sciara ocellaris. In: Genome Analysis in Eu- 
karyotes: Developmental and Evolutionary Aspects (Chatterjee, R.N. and Sánchez, L., eds.). Narosa Publishing House, New Delhi, pp. 149-166.

Perondini, A.L.P. and Dessen, E.M.B. (1985). Polytene chromosomes and the puffing patterns in the salivary gland of Sciara ocellaris. Rev. Bras. Genet. VIII: 465-478.

Perondini, A.L.P., Otto, P.A., Templeton, A.R. and Rogatko, A. (1983). Evidence for assortative mating systems related to the polytene chromosome-band polymorphism in Sciara ocellaris. J. Hered. 74: 283-288.
Perondini, A.L.P., Gutzeit, H.O. and Mori, L. (1986). Nuclear division and migration during early embryogenesis of Bradysia tritici Coquillet (syn. Sciara ocellaris) (Diptera; Sciaridae). Int. J. Insect Morphol. Embryol. 15: 155-163.

Sánchez. L. and Perondini, A.L.P. (1999). Sex determination on sciarid flies: a model for the control of differential X-chromosome elimination. J. Theor. Biol. 197: 247-259.

(Received January 20, 1999) 
